WellBeing International

WBI Studies Repository

$12-2004$

\title{
The Other Side of Silence: Rachel Carson's Views of Animals
}

Marc Bekoff

University of Colorado

Jan Nystrom

University of Utah

Follow this and additional works at: https://www.wellbeingintlstudiesrepository.org/acwp_awap

Part of the Animal Studies Commons, Natural Resources and Conservation Commons, and the Terrestrial and Aquatic Ecology Commons

\section{Recommended Citation}

Bekoff, M., \& Nystrom, J. (2004). The other side of silence: Rachel Carson's views of animals. Zygon ${ }^{8}$, 39(4), 861-884.

This material is brought to you for free and open access by WellBeing International. It has been accepted for inclusion by an authorized administrator of the WBI Studies Repository. For more information, please contact wbisr-info@wellbeingintl.org.

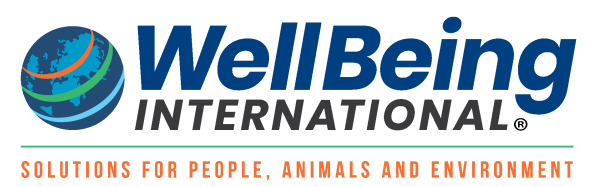




\title{
The Other Side of Silence: Rachel Carson's Views of Animals
}

\author{
Marc Bekoff $^{1}$ and Jan Nystrom ${ }^{2}$ \\ ${ }^{1}$ University of Colorado \\ ${ }^{2}$ University of Utah
}

\section{$\underline{\text { KEYWORDS }}$}

Rachel Carson, Silent Spring, And No Birds Sing, Lost Woods, animal welfare, animal rights, environmentalism, conservation biology, pesticides, DDT

\section{$\underline{\text { ABSTRACT }}$}

The publication of Rachel Carson's Silent Spring in 1962 is widely regarded as one of the major events that launched the modern environmental movement. Silent Spring is a compelling blend of stories, natural history, human values, and biological facts. In this essay we consider Carson's attitude toward animals in Silent Spring and in other texts. Despite the facts that she was raised to love Nature and animals, little direct attention has been given to Carson's views about our moral responsibilities to, and the moral standing of animals. Carson favored responsible stewardship, was more of an animal welfarist and environmentalist/conservation biologist who privileged ecosystems and species than an animal activist who privileged individuals, and she did not advocate an animal rights agenda. There is clear tension in Carson's text. Often she seemed troubled by attempting to come across as a moderate and practical scientist and some of her words, when considered out of context, could lead one to label Carson as an animal rightist. While some of Carson's text favors human-centered interests, she did not believe that only humans counted. Her warnings about silent springs - silent seasons - must be taken seriously, perhaps even more seriously than when they were penned more than four decades ago. Surely, on the other side of silence, await magic, awe, and Nature's cacophony of sounds - along with a panoply of innumerable other sensory (visual and olfactory) experiences that help us to feel at one with all of Nature. We must be careful never to allow Nature to be silenced. Carson was a passionate and extremely influential activist, and there is no doubt that if there were a world of Rachel Carson's in charge of our global environmental policies, we and our fellow animals would surely be in much better shape than we currently are.

\section{Rachel Carson and Animals: An Overview}

The publication of Rachel Carson's Silent Spring in 1962 is widely regarded as one of the major events that launched the modern environmental movement. Silent Spring is a compelling blend of stories, natural history, human values, and biological facts. It is about more than just the cumulative and devastating biological effects of pesticides ("biocides" or "elixirs of death") that result in environments that are devoid of melodious bird song. It is about life itself, focusing on the many different webs of Nature that go 
unnoticed, misunderstood, unappreciated, and unloved until we lose them. Silent Spring catalyzed grassroots movements, sparked a presidential investigation, raised awareness among the general public about the effects of pesticides, and resulted in the banning of DDT in the United States and the development of tests for pesticides.

Carson was a courageous activist with a practical bent. She exhorts us to reconsider the choices we make concerning our fundamental relationship to Nature, an alliance that should be teeming with appreciation, awe, humility, connection, harmony, and reverence rather than with dismissal, arrogance, control, distance, discord, and irreverence. Education is critical. Carson not only issued a wake up call for us to do something about how we destroy and desecrate Nature, but also demanded that we wake up our senses and our sensitivity, that we keep our senses alive.

In this essay we consider Carson's attitude toward animals in Silent Spring and in other texts. Despite the facts that she was raised to love Nature and animals, wrote beautiful, passionate, empathic, and sometimes anthropomorphic prose about animals, used anecdotes to celebrate the lives, beauty, and fates of individual animals, species, and ecosystems, spoke out about the use of such contraptions as live traps, and penned a strong and impassioned preface to a book about the appalling abuse and torture of animals in slaughterhouses in the United Kingdom, very little direct attention has been given to Carson's views about our moral responsibilities to, and the moral standing of animals. Many of the animal issues with which Carson was troubled are currently in the forefront of present day concerns. Carson used animals as indicators of environmental destruction and the well-being of ecosystems, and she deeply lamented their pains and suffering at the hands of humans. The absence of animals, their silence, is intolerable, and a marker - a warning - that something is very wrong. Their silence indicates that an ecosystem has been poisoned. Also, what befalls the animals befalls us as well.

Some of the specific questions with which we are concerned either directly or indirectly include: What were Rachel Carson's attitudes toward animals? Was she an animal activist? Was Carson an animal welfarist or an animal rightist? Did Carson "hold back" her more radical views about animals for fear she would alienate the general public and so undermine her goal of alerting them to the dangers of pesticides? Might she have been more open about her feelings about animals if she did not have another agenda? Was Carson conflicted about the way animals were used by humans for human ends? Did she have occasional human-centered leanings in her overall ethic of making the world a better place for all beings? Can Carson's views about people having a "right" to enjoy animals and Nature be reconciled with how she viewed the "rights" of people who hunt and fish? What would socially responsible science look like to Carson? Did Carson consider a "hands off" leave-it-alone policy as an alternative strategy for some of the issues with which she was concerned? Is Silent Spring, a book that is clearly a call to action and a personal vision, also a book of hope? Needless to say, many of these questions cannot readily be answered "yes" or "no."

While we cannot deal in detail with all of these or other questions that arise, we feel it is appropriate and instructive to look closely at Silent Spring to try to understand Carson's views on animals and animal wellbeing. We begin by discussing different positions on animal protection (animal welfare and animal rights) that inform decisions about animal use and policy, and then we review some issues with which animal protectionists, environmentalists, and conservation biologists are concerned. Next we consider a number of ways in which humans intrude on the lives of animals at different levels of organization ranging from ecosystems to species to populations to individuals. Human beings are an invasive species. We intrude intentionally and unintentionally on ecosystems and animals wherever and whenever we choose. But we really are part of the rest. We are part of the story and part of Nature's complicated and magnificent webs. Carson's primary concern was not necessarily with intentional human infringements, but with how we live, how the chemicals we were using were degrading the environment, poisoning animals, and silencing 
springs. Human infringements also include moving (translocating — introducing and reintroducing) animals from one ecosystem to another (often referred to as "redecorating" nature, see Bekoff 2000a, or "faking" Nature, see Elliot 1997), to trapping them, to using them for food, in education, in research, and for amusement and entertainment. Carson also wrote about some of these types of intrusions.

Next, we attempt to determine Carson's position on animal protection by closely analyzing Silent Spring and some of her other prose. Carson's lyrical and passionate language celebrates the lives of individual animals, but she also often defers to the "rights" of people, from bird-watchers to hunters, in justifying why we should protect ecosystems and thus the animals who live there, rather than deferring to the rights of the animals themselves. Carson writes in many tones ranging from reductionism to holism and she also freely comingles facts and values. Her prose range from that of a moderate animal welfarist to that of a more extreme animal rightist. Carson supports "reverence for all life," an attitude similar to that espoused by Albert Schweitzer, a man she clearly revered, and she decried the slaughterhouses in the United Kingdom and advocated for animals yet she often describes animals - and ecosystems - not in terms of their intrinsic value, but in terms of their value to humans. In some instances it may be impossible to say just where Carson falls in the animal protection arena. Often, if one were to guess who wrote some of Carson's words about animals she or he likely would not guess it was Carson herself who penned them. However, if we let her own words speak for themselves, it is possible to determine if and how Carson attempted to resolve conflicting views in her prose, and let individuals draw their own conclusions.

\section{Animal Welfare and Animal Rights: A Brief Overview}

In order to locate Carson's views on animals it is useful to review briefly some of the general differences between animal welfare and animal rights. Many animals suffer and feel pain (for general discussion see Bekoff 2000a, 2000b, 2002 and references therein). Since animals feel pain and suffer, we must be careful not to cause them unnecessary pain and suffering. While some people believe that it is all right to cause animals pain and suffering if humans benefit, there are others who believe that human benefits do not justify animal pain and suffering. There are also those who argue that it is all right to trade off individual animals for the good of their species, even if some individuals suffer and die. Most environmentalists and conservation biologists adopt this stance (Bekoff and Jamieson 1996; Bekoff 2001; see also Estes 1998).

People who believe that we are allowed to cause animals pain, but that we must be careful not to cause them excessive or unnecessary pain, argue that if we consider the animals' welfare or well-being, then that is all we need to do. These people are typically called welfarists. Welfarists are concerned with the quality of animals' lives. But welfarists do not believe that animals' lives are valuable in and of themselves, that it is just because animals are alive that their lives are important. Welfarists believe that if animals experience comfort, appear happy, experience some of life's pleasures, and are free from prolonged or intense pain, fear, hunger and other unpleasant states, then we are fulfilling our obligations to them. If individuals show normal growth and reproduction, and are free from disease, injury, malnutrition and other types of suffering, they are doing well. The welfarists' position also assumes that it is all right to use animals to meet human ends as long as certain safeguards are used. They believe that the use of animals in experiments and the slaughtering of animals for human consumption are all right as long as these activities are conducted in a humane way. Welfarists do not want animals to suffer from any unnecessary pain but they sometimes disagree among themselves about what pain is necessary and what humane care really amounts to. But welfarists agree that the pain and death animals experience is sometimes justified because of the benefits that humans derive. The ends, human benefits, justify the means, the use of animals, even if they suffer because their use is considered to be necessary for human benefits. 
Those people who believe that it is wrong to cause animals any pain and suffering, and that animals should not be eaten, held captive in zoos, or used in painful research, or in most or any research, are typically called rightists. They believe that animals have certain moral and legal rights that include the right not to be harmed and that animals' lives are valuable in and of themselves - their lives are not valuable because of what they can do for humans (their instrumental value) or because they look or behave like us. According to Gary Francione (2000), to say that an animal has a "right" to have an interest protected means that the animal has a claim, or entitlement, to have that interest protected even if it would benefit us to do otherwise. Humans have an obligation to honor that claim for other voiceless animals just as they do for young children and the mentally disabled. So if a grebe has a right to live in her native habitat then we have an obligation not to destroy or poison her home. For general discussion of the differences between animal welfare and animal rights see Regan 1983, Singer 1990 and Francione 2000. For discussion of how different views are related to conservation biology see Estes 1998, Bekoff and Jamieson 1996 and Bekoff 2000b, 2001, 2002.

Environmentalists and conservationists are usually more concerned with populations, species, and ecosystems than with individuals. But, some conservation biologists are troubled when making decisions about the relative value of individuals, versus species, populations, and ecosystems, and clearly so was Carson. It is worth quoting Jim Estes, a very experienced conservation biologist, on this general issue because he poignantly and succinctly gets to the heart of the matter in his discussion of whether or not to rehabilitate oiled wildlife, specifically California sea otters.

The differing views between those who value the welfare of individuals and those who value the welfare of populations should be a real concern to conservation biology because they are taking people with an ostensibly common goal in different directions. Can these views be reconciled for the common good of nature? I'm not sure, although I believe the populationists have it wrong in trying to convince the individualists to see the errors of their ways. The challenge is not so much for individualists to build a program that is compatible with conservation - to date they haven't had to - but for conservationists to somehow build a program that embraces the goals and values of individualists because the majority of our society has such a deep emotional attachment to the welfare of individual animals. . As much as many populationists may be offended by this argument, it is surely an issue that must be dealt with if we are to build an effective conservation program. (Estes 1998, 1157)

We can position Carson's views on animals (and the tension embodied in Carson's text) by visiting the ongoing debate between animal rightists and environmentalists and conservation biologists, rightists favoring rights for or privileging individual animals and environmentalists and conservation biologists typically favoring rights for, or privileging larger entities such as populations, species, or ecosystems. (It might be permissible for an individual to suffer or to die for the good of its species, though pain and suffering should be avoided whenever possible.) Carson is more of a practical welfarist, a stance usually adopted by most environmentalists and conservation biologists, than an animal rightist. She chronicles much about webs of Nature and webs of death and the importance of preserving Nature's integrity, its goodness and wholeness, in all terrestrial and aquatic ecosystems. Carson favored responsible stewardship. She privileged ecosystems and species over individuals, and surely did not advocate an animal rights agenda, although some of her words taken in isolation and out of context could lead one to the opposite conclusion. Although in her prose Carson often celebrates the lives of individual animals and describes them in very lyrical terms, her larger concern seems to be with healthy ecosystems and with how those ecosytems affect us humans. Carson supported sport fishing and, in Silent Spring, she noted that hunters' rights were being infringed upon when ecosystems were destroyed, but she also anguished 
over the sport killing of some sharks. She favored the introduction of non-native shrews to Newfoundland as an alternative to the use of pesticides. Clearly, some of her text favors human-centered interests, but she did not believe that only humans counted.

We want to stress that although we call attention to the fact that Carson should be considered more of an animal welfarist rather than a supporter of animal rights, this does not in any way lessen her significant impact on bettering the health of ecosystems and the well-being of numerous animals, and for calling attention to the horrific effects of pesticides and "big science," itself contaminated by people - scientists on the take - with vested interests in the pesticide industry. If there was a world of Rachel Carson's in charge of our global environmental policies we and our fellow animals would surely be in much better shape than we currently are.

\section{Redecorating and Silencing Nature: Human Intrusions into Animals' Lives}

Before analyzing in more depth Carson's view of animals, we want to review briefly some of the issues with which animal protectionists are concerned and also some of the positions that they hold concerning the use of animals by humans. We offer representative examples to make general and specific points that relate to Carson's concerns about the effect of pesticides.

Human influences, also called anthropogenic effects, are rampant. We are literally here, there, and everywhere. Just "being there," out in Nature and not handling animals, can influence their behavior (Bekoff and Jamieson 1996; Bekoff 2001; Bekoff 2002; Goodall and Bekoff 2002.). Humans make a difference - directly and indirectly, intentionally and unintentionally - in the lives of just about all terrestrial, aquatic, and arboreal animals. We are a powerful and dominating force in Nature, and we are an integral part of innumerable webs of Nature. And, along with our ubiquitous presence, come deep responsibilities to step lightly into the lives of other animals. In his novel Prey, Michael Crichton writes of "the obstinate egotism that is a hallmark of human interaction with the environment" (2002, xii).

Not only do we influence the lives of other animals in an immediate sense, but we also can effect long lasting and enduring changes in their behavior (Bekoff 2004). Global warming is influencing the distribution and behavior of animals and resources such as food, water, and resting spots. It has been predicted that between $15 \%$ and $37 \%$ of species could go extinct between now and 2050 due to global warming. Trophy hunting is reducing the average size of horns among bighorn sheep because large rams with big horns are selectively picked off. Selective hunting influences mating behavior such that there is less head-butting among males for access to rams, and there might even be an influence on population genetics among these mountain monarchs. Humans can rapidly change the feeding habits of bears who live around dumpsters so that they become active during the night rather than during the day to avoid humans, and these bears become obese and lazy. Fast food makes them fat. They also enter dens later in the fall and remain in them for shorter periods of time than do bears who do not forage at dumps. Hormones from cattle feedlots can demasculanize males and defeminize wild fish. Fishing can induce sex changes in fish and animals such as cougars, coyotes, foxes, and deer often become so habituated to humans that rather than flee from us they become bold and curious and intrude into our neighborhoods. Often researchers inadvertently harm the very animals they want to study. Knowledge of how we affect the behavior of animals can help us make more informed and intelligent choices about how we interfere in their lives. There is also ample evidence that pesticides and other forms of environmental pollution affect the behavior of many animals (DellOmo 2002; Burger 2004).

Carson $(1962,245)$ was very concerned about humans' attempts "to mold Nature to our satisfaction," to "redecorate Nature" (Bekoff 2000a, 2000b, 2003). Animals are non-consenting participants in these encounters and may also be, as Carson $(1962,85)$ sympathetically notes, "incidental victims." Carson 
was raised to love Nature and as a youngster she wrote stories about her own experiences exploring her surroundings. Her philosophy about animals and other Nature was clearly informed by her early experiences. In Carson's own words:

From what I have told you, you will know that a large part of my life has been concerned with some of the beauties and mysteries of the earth about us, and with even greater mysteries of the life that inhabits it. No one can dwell long among such subjects without thinking rather deep thoughts, without asking himself searching and often unanswerable questions, and without achieving a certain philosophy. (Lear 1997, 159)

Later we will return to what Carson might have thought about the havoc, the pain and suffering and death, that we cause for innumerable innocent animals each and every second of each and every day.

Humans silence animals when we intrude into their lives and tamper with who they are and the habitats in which they have evolved or live nowadays. Often, melodious bird song and a wide variety of soothing and raucous sounds are extinguished. Likewise, in addition to the loss of sounds, we suffer the loss of other sorts of silences when we lose the force of other sensory experiences - symphonies of visual images and odors - all of which are important in celebrating the presence of other animals. However, it was silent springs that served as a clear warning that something bad was happening to the habitats in which birds lived, and we should indeed fear that silent springs may be followed by silent summers, winters, and falls if we do not change our ways and change them rapidly today, not tomorrow.

When humans interact with Nature we frequently wind up redecorating it, selfishly. Intentionally or not, it is as if humans have a powerful inborn urge to "reshape" Nature, to "recreate" Nature, to "restore" Nature, so as to expand our horizons with few if any boundaries. It is as if we just cannot stop ourselves, and little else does, even the blatant, often horrific results, of our trying to dominate - manage, control - our surroundings. We move animals around as we move furniture, and we redecorate landscapes with little concern for maintaining biological integrity. Even during strolls in pristine forests, swims in oceans, or forays in the sky, many humans are detached and alienated from the majesty of their surroundings. It seems as if we do not love Nature deeply, and that we would not miss Nature and wilderness that are disappearing at unprecedented and alarming rates.

Human intrusions occur on different spatial and temporal scales and on various levels. We influence individuals, populations, species, and ecosystems and in most, perhaps in all instances, there are interactions among the different levels. Removing one individual from a group of animals can influence not only that group but also the behavior of other groups of animals, and there are domino effects that can influence reproduction within species, populations, and entire ecosystems. As Carson and many others have noted, there are intricate and interconnected webs of Nature and these webs can be very fragile.

\section{Webs of Nature: Coyotes, Cats, Scrub Birds, and Silence}

Much of Silent Spring and Carson's other writings are concerned with the innumerable ways in which human activities disrupt the close interconnections of members of the earth community (see also Lear 1997; Cafaro 2002). She presents case after case of humans intruding on, destroying, and silencing ecosystems and intimately interconnected webs of Nature to make her general and specific points, similar to many who write on animal issues that do not involve the effects of pesticides.

The opening parable of Silent Spring portrays a healthy ecosystem as one in which humans and all other animals live in harmony, yet while Carson laments the loss of animal lives, her inclusion of animals often is cast largely in the value they bring to humans, bird-watchers and those who enjoy fishing or hunting. It 
is instructive to consider Carson's attitude towards animals because it highlights many of the complex issues and our complex views of animals, and also focuses attention on current debates and points of conflict between animals protectionists, environmentalists, and conservation biologists.

Carson was concerned with our attempts "to mold Nature to our satisfaction" $(1962,245)$. The words she chose might reflect one way in which Carson attempted to resolve tension in her views about humans' proper relationship to Nature. Some of Carson's most moving, empathic, and anthropomorphic prose refers to webs of Nature and their disruption and devastation. She displays deep empathy. Indeed, Carson wrote of "chains of devastation" when she referred to the death of robins as a result of a program to spray elm trees with pesticides, "one of the multitudinous spray programs that cover our lands with poisons" $(1962,109)$. About 90 species of birds, ground, treetop and bark feeders and predators, suffered heavy mortality in this program.

Carson emphasized that we are all interconnected. When she wrote about the effect of arsenic on water pollution and the widespread occurrence of cancer she noted, "Here again we are reminded that in Nature nothing exists alone" (Carson 1962, 51). When she wrote about soil Carson stressed that the soil community "consists of a web of interwoven lives, each in some way related to the others - the living creatures depending on the soil, but the soil in turn a vital element of the earth only so long as this community within it flourishes" $(1962,56)$. Carson also wrote: "For each of us, as for the robin in Michigan or the salmon in the Miramichi, this is a problem of ecology, of interrelationships, of interdependence" $(1962,189)$. When Carson wrote about inshore waters she noted,

The inshore waters - the bays, the sounds, the river estuaries, the tidal marshes - form an ecological unit of utmost importance. They are linked so intimately and indispensably with the lives of many fishes, mollusks, and crustaceans that were they no longer habitable these seafoods would disappear from our tables. $(1962,149)$

This last quote, however, stresses not only the interconnectedness of all things, but also human interests, and raises the question if Carson would have been concerned with the absence of these animals as more than culinary delights. We believe she would have and will return to this question later.

People interested in animals and conservation also are keenly interested in webs of Nature. Not surprisingly, the absence of close and reciprocal links among members of a community, however subtle, is the exception rather than the rule. Let me mention two recent examples. Joel Berger and his colleagues (2003) note that while the notion of top-down regulation of communities by carnivores in terrestrial ecosystems has been controversial, their analyses lend support to top-down regulation in the Jackson Hole area of the Greater Yellowstone Ecosystem. In Yellowstone Park there is evidence of an inverse relationship between wolf densities and elk abundance along with associated increases in the height of aspen suckers as elk densities decline (see also Smith 2003).

There are also complex webs of Nature that, when disrupted, can lead to "silence," the loss of birdsong. Kevin Crooks and Michael Soulé (1999) discovered complex interrelationships among coyotes, other predators (called mesopredators) such as domestic cats, opossum, and raccoons, and scrub birds including California quail, wren tits, spotted towhees, Bewick's wrens, California thrashers, greater roadrunners, cactus wrens, and California gnatcatchers living near San Diego, California. Their research is an example of the importance of long-term projects that investigate complex webs of Nature that are not obvious at first glance. Crooks and Soulé found that scrub bird diversity, the number of different species present, was higher in areas where coyotes lived. Domestic cats, opossum, and raccoons avoid coyotes by shunning areas where coyotes are most active and birds benefit. The disappearance of a dominant carnivore, the coyote, resulted in elevated numbers and activity of mesopredators who exert 
strong predation pressure on native prey species. Crooks and Soule also discovered that the level of bird predation by mesopredators appeared to be unsustainable. Extinctions of scrub-breeding birds are frequent and rapid. At least 75 local extinctions may have occurred in their study areas over the past century.

\section{Moving Animals from Place to Place: Redecorating and Managing Ecosystems}

Moving animals from one place to another, or translocating them, is very often used to help endangered or imperiled species. Often animals are reintroduced to ecosystems (about $65 \%$ of translocation projects involve reintroducing species to areas where they once lived; Tear et al. 1993) in which their numbers have dwindled or in which they have been exterminated (for example, reintroducing gray wolves to Yellowstone National Park, Smith 2003, and Canadian lynx to Southwestern Colorado, Bekoff 2001). Animals are also introduced to areas where they are not native. While Carson does not write much at all about translocation projects she notes in her discussion of natural solutions to insect infestations that non-native masked shrews were introduced in 1958 to Newfoundland to prey on problematic sawflies (Carson 1962, 296). Carson favored this strategy. Although translocation was not a major concern of Carson's, she advocated the introduction of shrews as an alternative to chemical pesticides but probably had not thought through the ramifications of introducing a non-native species. By 1962 shrews had spread over the island. Surely there are ethical issues that need to be addressed, for the introduction of non-native species is a form of "control of Nature" (Carson 1962, 297) and can greatly influence webs of interactions and the integrity of an ecosystem.

\section{Carson and Individual Animals}

...I had to think myself into the role of an animal that lives in the sea. To bring this about I had to forget a lot of human conceptions. For example, time measured by the clock means nothing to a shorebird. His measure of time is not an hour, but the rise and fall of the tides - exposing his food supply or covering it again. (Carson 1998, 56)

Carson was concerned with and celebrated individual lives (and also species and ecosystems) with beautiful empathic and anthropomorphic prose. When Carson observed other animals, she tried to imagine what it was like to be those animals: "I was successively a sandpiper, a crab, a mackerel, an eel, and half a dozen other animals" (Carson 1998, 56). She decried factory farms in the United Kingdom, was incensed by cruel predator control programs and the federal government's wanton poisoning of wildlife, and also became a member of the board of Defenders of Wildlife a short while before she died (Brooks 1972).

As an example of her sensitivity to an individual animal, consider a letter Carson wrote to her friends Dorothy and Stanley Freeman (Carson 1998, 169-170). Carson had taken a midnight hike with her niece and grand-nephew when they saw a firefly who was flying low over the water at risk of getting caught by a wave. At first, Carson was puzzled by his strange behavior but then she realized what he was doing. She wrote:

... he was flying so low over the water that his light cast a long surface reflection, like a little headlight. Then the truth dawned on me. He "thought" the flashes in the water were other fireflies, signaling to him in the age-old manner of fireflies! (Carson 1998, 170)

The firefly wound up mired in wet sand. Carson goes on to write: "You can guess the rest: I waded in and rescued him ... and put him in Roger's bucket to dry his wing" $(1998,170)$. This passage is significant because Carson refers to a firefly as an individual (a "he") rather than an object (an "it"). She attributes cognitive abilities to the firefly by noting that he "thought," although she qualifies this statement by putting 
the word thought in quotation marks. Finally, and perhaps most importantly, Carson considers it worthwhile to save the life of this firefly.

Carson also describes play by herrings, being freely anthropomorphic and expressing great sensitivity:

Then the herring would begin flipping into the air. It seemed it was always out of the corner of your eye that you saw them, and you never quite knew where to look for the next little herring skipping recklessly into the air in a sort of back somersault. They did it as though it were great fun - this rash defying of a strange and hostile element, the air. I believe it was a sort of play indulged in by these young children of the herring. $(1998,37)$

Carson also wrote of the parental care of swifts:

Swifts are devoted parents. The male and female take turns incubating the eggs during the nearly three weeks required for the young to hatch. Thereafter, both birds assume the chore of keeping the infant mouths filled with insects, a task that must be performed faithfully for about four weeks before the young swifts are able to take to the sky in their own behalf. $(1998,27)$

Carson also refers to old fish as "patriarchs of the river" $(1962,146)$.

Carson's observations of animals are reminiscent of the observational methods of such ethologists as Konrad Lorenz and Niko Tinbergen, and her identification with individual animals reminds us of the question that guides many students of behavior (Bekoff 2002) - "What is it like to be this or that individual?" When many ethologists observe other animals they try to become that individual — "I am coyote" or "I am raven" - in order to come to a fuller understanding of what it is like to be that creature (Bekoff 2002). This of course necessitates both an imaginative grasp of, and an empathetic connection with, the lives of other animals.

\section{Carson's Preface to Animal Machines: Animals as Food}

Carson also was very concerned about the use of animals as food for humans. Carson was not a vegetarian (Linda Lear, personal communication, 30 July 2003). In Carson's preface to Ruth Harrison's book Animal Machines, about factory farming in the United Kingdom, Carson wrote:

Gone are the pastoral scenes in which animals wandered through green fields or flocks of chickens scratching contentedly for their food. In their place are factorylike buildings in which animals live out their wretched existences without ever feeling the earth beneath their feet, without knowing sunlight, or experiencing the simple pleasures of grazing for natural food - indeed, so confined or so intolerably crowded that movement of any kind is scarcely possible. $(1998,194)$

This passage contains strong language reminiscent of that of animal rightists.

Carson also wrote:

I am glad to see Mrs. Harrison raise the question of how far man has a moral right to go in his domination of other life. Has he the right, as in these examples, to reduce life to a bare existence that is scarcely life at all? Has he the further right to terminate these wretched lives by means that are wantonly cruel? My own answer is an unqualified no ... Man will never be at peace with his own kind until he has recognized the Schweitzerian 
ethic that embraces decent consideration for all living creatures - a true reverence for life. $(1998,196)$

Once again these are strong and critical words. But, we may ask, what about methods that are not wantonly cruel? Would raising animals for human consumption be permissible under these conditions?

Carson was a pragmatist in her view of animals. Linda Lear noted:

...Carson quietly aided the work of [Christine] Stevens and the Animal Welfare Institute, writing to members of Congress in support of legislation banning the use of certain leg taps and against the inhumane treatment of laboratory animals. But she had to be careful not to draw too much attention to her support for causes that might link her in the public mind with fringe groups and extremists, lest she jeopardize her all-important work concerning the misuse of pesticides. Had this not been a real political consideration, Carson undoubtedly would have been an outspoken advocate of the humane treatment of animals. (1998, 192-193)

Lear further clarified this point:

The point I was making on p. 193 has to do with the chronology of Carson's life. She, cleverly, in my view, agreed to write that hard hitting forward to Animal Machines for a British book which she was fairly confident would not be widely read or known in the U.S. press. So she felt free to speak out. She wrote this in 1962, late, for publication in 1963. But at home the furor over SS [Silent Spring] was raging and her enemies were looking for ways to discredit her science and that meant looking for ways to call her a "kook." Being a radical animal rightist, or radical organic foods advocate meant being a communist, and certainly being far worse than the "bird and bunny lover" they had dubbed her. Such causes were ones she deeply believed in but were "peripheral" in 1963 to being heard and having her scientific evidence against the misuse of pesticides and its possible links to cancer be heard. If you put this statement in context to the fact that she was attacking corporate America and the agricultural economic breadbasket, you can see her point. (personal communication, 8 July 2003)

Carson also recognized the power of the consumer in bringing about change, an argument put forth by animal protectionists. Public outcries about the way in which veal calves are raised resulted in a drastic decline in the consumption of veal. To this end, Carson wrote: "I hope it [Animal Machines] will spark a consumers' revolt of such proportions that this vast new agricultural industry will be forced to mend its ways" $(1998,196)$. But what about the possibility of closing the industry down? Why not accept that factory farming cannot be humane for the individuals involved? Individuals suffer not only when they are mistreated but also when they hear, smell, and see other individuals being harmed and killed.

Indeed, today factory farming remains a huge environmental and animal rights issue. Worldwide, more than 25 billion animals are killed each year in the meat industry; about three million individuals are killed each hour. Chickens are debeaked, pigs have their tails chopped off and their teeth pulled with pliers, and bulls and pigs are castrated. In the United States alone, more than eight billion animals are killed annually for food. In 2000 and 2001 there was a record high 46 billion pounds of red meat production (cattle, veal, pork, lamb, and mutton). Huge amounts of grain, forage, and land are used in food production. Animals consume more protein than they produce. For every kilogram (2.2 pounds) of animal protein produced animals consume about six kilograms (more than 13 pounds). One kilogram of beef requires about 100,000 liters of water, whereas one kilogram of wheat requires about 900 liters of water. The meat 
industry causes more water pollution in the U.S. than all other industries combined. An average pig farm generates raw waste equal to a city of 12,000 people.

It is worth noting the connection between meat consumption and the use of pesticides. Pesticide advocates note that pesticides increase crop yield and thus have an important role to play in addressing world hunger. However, many of the crops produced are simply fed to livestock, which is an inefficient use of resources. For example, the number of people whose food energy needs can be met by the food produced by 2.5 acres of land is one person if the land is producing beef, two people if the land is producing chickens, but 15 people if the land is producing wheat, and 19 people if the land is producing rice (data are from Weil 2003). If Americans simply reduced beef consumption by $10 \%$, we could save 12 million tons of grain, the amount needed annually to feed every person who dies of hunger or hungerrelated illness. Simply put, if we decrease meat consumption we would not need to resort to pesticides to increase crop yield.

\section{Animals in Education and Research}

Carson also wrote briefly about the use of animals in education and research. Millions upon millions of individuals are used in all levels of education and research worldwide (Bekoff 2002). Carson even sent a message to a congressional committee urging federal standards for the protection of animals used in research (Brooks 1972, 317).

But, as in some of her prose about the use of animals for food, Carson took a moderate stance. In her essay To Understand Biology Carson wrote:

To the extent that it is ever necessary to put certain questions to Nature by placing unnatural restraints upon living creatures or by subjecting them to unnatural conditions or to changes in their bodily structure, this is a task for the mature scientist. It is essential that the beginning student should first become acquainted with the true meaning of his subject through observing the lives of creatures in their true relation to each other and to their environment. $(1998,193-194)$

She continues:

To begin by asking him to observe artificial conditions is to create in his mind distorted conceptions and to thwart the development of his natural emotional response to the mysteries of the life stream of which he is a part. Only as a child's awareness and reverence for the wholeness of life are developed can his humanity to his own kind reach its full development. $(1998,194)$

There are a number of questions that can be asked about Carson's stated position. For example, is it "ever necessary to put certain questions to Nature by placing unnatural restraints upon living creatures or by subjecting them to unnatural conditions or to changes in their bodily structure" even for the mature scientist? What would Carson think about biomedical research? Is it ever necessary? It appears that Carson's position would sanction some biomedical research if it helped humans.

\section{Alternatives to the Use of Animals}

Under the philosophy that now seems to guide our destinies, nothing must get in the way of the man with the spray gun. (Carson 1962, 85) 
We must make wider use of alternative methods that are now known, and we must devote our ingenuity and resources to developing others. (Carson 1962, 138)

Carson was surely concerned about animal well-being but comes across as a moderate welfarist. She did not seriously consider taking a hands-off policy in most instances (she did posit some natural alternatives to the control of pests) and did indeed often come down on the side of humans despite prose that would suggest otherwise. To be fair, Carson argued that both nonhuman and human losses were important and she did lament the loss of natural landscapes and ecosystems by the introduction of chemical pesticides and various sorts of control programs. She wrote about the devastating effects of pesticide spraying as follows:

I know well a stretch of road where Nature's own landscaping has provided a border of alder, viburnum, sweet fern, and juniper with seasonally changing accents of bright flowers, or fruits hanging in jeweled clusters in the fall. But the sprayers took over and the miles along that road became something to be traversed quickly, a sight to be endured with one's mind closed to thoughts of the sterile and hideous world we are letting our technicians make. But here and there authority had somehow faltered and by an unaccountable oversight there were oases of beauty in the midst of austere and regimented control - oases that made the desecration of the greater part of the road the more unbearable. $(1962,71)$

Carson goes on to note that, "In such places my spirit lifted to the sight of the drifts of white clover or the clouds of purple vetch with here and there the flaming cup of a wood lily" $(1962,71)$.

Carson did propose some natural alternatives to the use of pesticides. She urged people to pay more attention to the role of plant-eating insects $(1962,83)$, noted that imported parasitic insects had been used to establish natural control of pests $(1962,96)$, stressed the use of natural parasites in keeping budworms under control $(1962,138)$, and noted that around the year 1800 Erasmus Darwin suggested that insects may be controlled by using their enemies. As mentioned above, Carson also favored the introduction of non-native shrews to Newfoundland to prey on sawflies.

\section{Locating Rachel Carson: Textual Tensions and Responsible Stewardship}

I am saying, rather, that the control must be geared to realities, not to mythical situations, and that the methods employed must be such that they do not destroy us along with the insects. (Carson 1962, emphasis added)

Much of Carson's reputation rests on her ability to place the meanings of scientific ecology within an ideology of species preservation. In her beautiful descriptions of the daily round of animal communities, she stressed the importance of each species to the survival of the whole. Such knowledge demanded respect for all life and, Carson hoped, more restraint in dealing with animal populations. Her angry outburst against hunting sprang in part from her concern for the potential extinction of valuable species, but it also evoked the pain caused to a single animal. This interest in the rights of individual animals as well as endangered species formed a critical part of Carson's message. (Norwood 1993, 161)

[Carson] felt little contradiction between protection of species and human treatment of individual animals; these were complementary goals equally necessary to a holistic ethic of human-animal relations. Nor was there a hierarchy of concern for domestic over wild animals. (Norwood 1993, 161) 
Carson was a prolific writer and openly and passionately shared her views with a wide audience. Linda Lear notes that Carson believed that Nature writers had a "moral obligation to bring the wonders of the natural world to the general public and urged them to accept that responsibility" (Carson 1998, 93). In Carson's own words:

My own guiding purpose was to portray the subject of my sea profile with fidelity and understanding. All else was secondary. I did not stop to consider whether I was doing it scientifically or poetically; I was writing as the subject demanded. $(1998,91)$

Brooks wrote of Carson's prose: "the merged imagination and insight of a creative writer with a scientist's passion for fact - goes far to explain the blend of beauty and authority that was to make her books unique" $(2000, x v)$. Lear noted that:

Rachel Carson's use of poetic language does not take away from the accuracy of her claim that her guiding purpose was to portray her subject with fidelity and understanding, without consideration of whether she was doing it scientifically or poetically. Accuracy and beauty were never antithetical qualities in her writing. $(1997,219)$

As mentioned above, Rachel Carson's attitude toward animal protection is that adopted by most mainstream environmentalists and conservation biologists: by living in harmony with Nature, man benefits not only himself, but also all animals. Her text reflects the ongoing debate between animal rightists, environmentalists, and conservation biologists and she can be placed squarely in the environmentalist's and conservation biologist's camp (for general discussion see Hargrove 1992; Zimmerman et al. 1993; Jamieson 1998). This is best exemplified in Carson's opening fable in which she portrays a world in which man lives in harmony with Nature and his fellow creatures: his crops flourish and his life is graced by bird song, but in the evenings the deer come out to play and the fox can be heard yipping in the distance. Within this parable, however, man still claims dominion. The world of Carson's fable is far from wilderness; it is a farm in which man, as steward, has selected which crops to plant and has largely defined the landscape. Given his dominion, Carson argues that man should be a responsible, compassionate steward (for further discussion of the notion of stewardship from theological and secular perspectives, see Wunderlich 2004).

Carson's attitude, however, does not answer or consider some of the ethical considerations posed by animal rightists and welfarists. Although importing shrews and fostering colonies of ants are far preferable methods for dealing with noxious insects than spraying DDT, there are still ethical questions that need to be addressed: Is it acceptable for man to "play God" by introducing non-native species in the case of the shrew, and if so, why? Why is it acceptable for the "mature scientist" (Carson's own words) to do some animal experiments, but not the student? Do hunters and fishermen have a right to pursue their game and does their right provide justification for maintaining healthy ecosystems? Can we morally justify the value of healthy bird populations by invoking not the intrinsic value of bird life, but the right of birders to enjoy bird watching? Does man's dominion over Nature, based on his technological superiority, necessitate that man attempt to control Nature or restore ecosystems? When, if ever, should we leave Nature alone? (Carson does argue for natural seashores.) Does an individual animal's life have value or is it only species that have value? Is it morally acceptable to eat animals as long as the animals are treated humanely and killed painlessly?

Although these questions are not explicitly articulated by Carson, these issues nonetheless inform Silent Spring and some of her other works. Carson's most lyrical, evocative prose celebrates the beauty of individual animals yet the basic argument put forth in Silent Spring has human-centered leanings that wax and wane in many of Carson's writings. The rights of people are being infringed upon when chemicals are 
sprayed on the environment; man has a right to hunt, a right to enjoy Nature's beauty and go bird watching, and a right to live free of the insecticides which inevitably affect not only animals but man himself. Within this paradigm, however, what are the rights of animals? Do they have any intrinsic value or intrinsic rights?

To pose these questions is not to criticize Carson. Surely a world of Carson's opening fable would benefit humans and our fellow creatures. Carson ultimately advocates a form of welfarism perhaps best characterized as "responsible stewardship." The ethical dilemmas regarding animal's role in man's world are among the same issues faced today. All of these issues raise questions about what is man's proper role in relationship to Nature: is it tyrant or responsible steward or fellow creature? And, perhaps more importantly, the question is not what is our role but what should our role be?

While Carson spoke out loudly and clearly for responsible stewardship by typically adopting a moderate, realistic, practical and frequently human-centered and welfarist stance on the issues at hand, it is plausible to conclude that she might have suffered from some dissonance between the beautiful words she spoke and wrote and what she truly felt in her heart and wanted to happen. Linda Lear agreed that Carson was a practical utilitarian and "was so bottled up but so powerful" (personal communication, 9, July 2003). Carson's connections with Christine Stevens and the Animal Welfare Institute (she was presented with the Schweitzer Medal of the Animal Welfare Institute), her indebtedness to Albert Schweitzer and his philosophy of reverence for all life, her stand against the use of steel leghold traps, and her Preface to Animal Machines all suggest that she held more "radical" beliefs than she publicly aired. Her use of fables about idealized and healthy ecosystems that define our proper relationship to Nature and other animals reflects a deep commitment to making the world a better place for all beings. Waddell argues that "A Fable for Tomorrow," the opening chapter of Silent Spring, is an "apocalyptic vision" $(2000,9)$. Lear claims that the opening fable was "a scary hoax, pure science fiction" and that many reviewers were "unable to understand its basis in allegory and used it to further demean her credibility as a scientist" (1997, 430).

Lear also notes that Carson was passionate about animals but kept her views relatively private. She did not want to have critics use her advocacy for animals "to belittle her science" $(1997,371)$. In addition to her concerns about not being taken seriously because she was not a professional scientist, Carson was also accused of having communist sympathies (Waddell 2000, 157) and of being a woman who was overly sensitive and sentimental. Her critics were by and large members of a male-dominated technology. Carson also relied on anecdotes which, for most scientists, do not constitute "hard" evidence. But, the plural of anecdote is data (Bekoff 2002).

Nonetheless, as we pointed out above in our discussions of the use of animals for food and in research and education, Carson was careful to put forth a moderate agenda about animal exploitation. In Silent Spring Carson wrote: "By acquiescing in an act that can cause such suffering to a living creature, who among us is not diminished as a human being?" $(1962,100)$. Hunting and fishing, two activities that Carson seemed to support (in Silent Spring and other texts, she referred to the "rights" of hunters) surely cause pain and suffering. Would Carson have argued that a humane death is permissible? Carson also accepted that hunting, when kept in balance, is a valid use of government land including hunting on wildlife refuges, but she lamented the killing of individual sharks (Gartner 1983).

It is common for there to be a disconnect between what people say and feel and what they do. Some people who might rescue animals from shelters or pick up stray dogs and cats and who claim to "love animals" also eat meat from cruel slaughterhouses and factory farms and wear leather. 
There is tension in a number of areas of Carson's writing including: 1) what should we do, 2) what should we believe, 3) who should we believe, and 4) what are the rights of Nature and the rights of humans to enjoy Nature and to hunt and fish. Consider the following quotations from Silent Spring about our proper relationship to Nature and to our fellow animals:

But what of the opposite end of the food chain - the human being who, in probable ignorance of all this sequence of events, has rigged his fishing tackle, caught a string of fish from the waters of Clear Lake, and taken them home to fry for his supper? What could a heavy dose of $D D D$, or perhaps repeated doses, do to him? $(1962,49)$

Such poisoning of waters set aside for conservation purposes could have consequences felt by every western duck hunter and by everyone to whom the sight and sound of drifting ribbons of waterfowl across an evening sky are precious. $(1962,45)$

To the bird watcher, the suburbanite who derives birds in his garden, the hunter, the fisherman or the explorer of wild regions, anything that destroys the wildlife of an area for even a single year has deprived him of pleasure to which he has a legitimate right. (1962, 86)

This is a problem that concerns a great many people. Some 25 million Americans look to fishing as a major source of recreation and another 15 million are at least casual anglers. These people spend three billion dollars annually for licenses, tackle, boats, camping equipment, gasoline, and lodgings. Anything that deprives them of their sport will also reach out and affect a number of economic interests. $(1962,139)$

The fisheries of fresh and salt water are a resource of great importance, involving the interests and the welfare of a very large number of people. That they are now seriously threatened by the chemicals entering our waters can no longer be doubted. $(1962,152)$

Carson uses the word "rights" to refer to the interests of people in having healthy ecosystems in which to hunt and recreate. She does not address the "rights" of the animals who live in these areas.

Clearly Carson favors human-centered interests, but there always seems to be some ambivalence about this attitude. For example, although she did not condemn sport fishing, Carson was very upset when she considers the killing of a shark for sport. She wrote:

Then one sees the slender shapes of sharks moving in to the kill. There was something very beautiful about those sharks to me - and when some of the men got out rifles and killed them for "sport" it really hurt me. $(1998,154)$

\section{What Can We Do and Who Should We Believe?}

Carson, as an activist, was extremely concerned with what could people do about the dire situation surrounding the use of pesticides and also about scientists (and others) "on the take," scientists and government officials with competing interests who were working for pesticide companies. Clearly there were conflicts of interest.

Carson wrote harsh words about scientists "on the take":

This situation also explains the otherwise mystifying fact that certain outstanding entomologists are among the leading advocates of chemical control. Inquiry into the 
background of some of these men reveals their entire research program is supported by the chemical industry. $(1962,259)$

The credibility of the witness is of first importance. The professional wildlife biologist on the scene is certainly best qualified to discover and interpret wildlife loss. The entomologist, whose specialty is insects, is not so qualified by training, and is not psychologically disposed to look for undesirable side effects of his control program. Yet it is the control men in state and federal governments - and of course the chemical manufacturers - who steadfastly deny the facts reported by the biologists and declare they see little evidence of harm to wildlife. $(1962,87)$

Who has decided - who has the right to decide - for the countless legions of people who were not consulted that the supreme value is a world without insects, even though it be also a sterile world ungraced by the curving wing of a bird in flight. The decision is that of the authoritarian temporarily entrusted with power; he has made it during a moment of inattention by millions to whom beauty and the ordered world of Nature still have a meaning that is deep and imperative. $(1962,127)$

Concerning the last quotation, we can also ask what about non-consenting animals, individuals who do not have the ability or the right to decide their fate when the rights of animals and people are in conflict?

Carson also wanted to put forth a positive message to children.

It is hard to explain to the children that the birds have been killed off, when they have learned in school that a Federal law protects the birds from killing or capture. "Will they ever come back" they ask, and I do not have the answer. The elms are still dying, and so are the birds. Is there anything being done? Can anything be done? Can I do anything? $(1962,103)$

However, it was difficult at the time to be especially hopeful.

\section{Silent Spring, Hope, and Humility}

Have we fallen into a mesmerized state that makes us accept as inevitable that which is inferior or detrimental, as though having lost the will or the vision to demand that which is good? $(1962,12)$

Rachel Carson was an extraordinary passionate woman and Silent Spring is an extraordinary passionate book. But, is Silent Spring a book of hope? Yes and no. Carson surely is a hero but heroes are not always hopeful. Nonetheless, we tend to want to make heroes positive. Silent Spring is dedicated to Albert Schweitzer and includes the following three quotations, the first by Schweitzer.

Man has lost the capacity to foresee and to forestall. He will end by destroying the earth. - Albert Schweitzer

The sedge is wither'd from the lake, And no birds sing. - John Keats

I am pessimistic about the race (sic) because it is too ingenious for its own good. Our approach to Nature is to beat it into submission. We would stand a better chance of survival if we accommodated ourselves to this planet and viewed it appreciatively instead of skeptically and dictatorially. - E.B. White

None of these statements is especially hopeful. 
Clearly, Rachel Carson was and remains an incredibly influential woman. Why is this so? Carson was an activist with a heart and opposed many practices in which humans interact with other animals, encounters that animals usually lose. She warned us not to take for granted nor squander Nature's melodies. After all, it was her and others' concerns about the loss of animals' voices that prompted her to write Silent Spring as a call to action for what was being done to the environment by the indiscriminate and irresponsible use of pesticides. But wasn't her concern about pesticides finally a concern about us? If we poison the natural world animals may die first but we will follow. Carson herself was dying of cancer.

Carson also mandated that we must abandon our attitude of controlling Nature and concluded Silent Spring as follows:

The "control of Nature" is a phrase conceived in arrogance, born of the Neanderthal age of biology and philosophy, when it was supposed that Nature exists for the convenience of man. The concepts and practices of applied entomology for the most part date from that Stone Age of science. It is our alarming misfortune that so primitive a science has armed itself with the most modern and terrible weapons, and that in turning them against the insects it has also turned them against the earth. $(1962,297)$

Note that Carson does not go on to write anything like "but there is hope if we do something about it." But, clearly, Carson attempted to do much about the harm we were causing to Earth; she devoted much of her short life to making the world a better place for all beings. While Carson does not invoke much hope, the very act of writing books, of tirelessly and selflessly reaching out so as to raise consciousness and to call people to action, are acts of hope - why write a book or travel about and expose oneself to personal insult and criticism if all is lost?

The issues with which Carson was concerned are difficult, challenging, frustrating, complicated, and strongly personal in many ways. Many remain with us today, for example: scientists on the take (Cornwell 2003; Krimsky 2003a, 2003b), pesticide companies taking their time to clean up their messes (Pearce 2003), the protection of pesticide manufacturers (Eisler 2003), increased use of pesticides worldwide (Huff 1998; Wood 1997), behavioral changes in animals due to pesticides (DellOmo 2002; Lee 2003; Burger 2004), and the negative effects of pesticides on reproduction in humans (Izakson 2004) and animals (Lee 2003). There is also evidence that immigrant workers suffer greatly from exposure to pesticides and that their only options are "shutting up or getting out" (Clarren 2003, 7).

Carson's final essay in Lost Woods eloquently captures her views, laden with humility and humbleness. In a letter to her friend, Dorothy Freeman, Carson reflected on the life cycle of the monarch butterfly. Her reflections on death, as part of the natural cycle of life, bring together many themes: humans' relationship to something larger, the beauty of Nature, the beauty of animals, and the need for humility and connection. So, it is important to stress that although there are occasional human-centered leanings in Carson's work - she does trump animal interests with human interests in areas where stronger and more zealous animal advocates would not - who among us does not occasionally share and implement these sentiments? It is indisputable that Carson deeply loved Nature and animals. Perhaps the tensions she experienced reflect those shared by many of us in trying to live ethically and step lightly with grace, care, compassion, humility, beneficence, and love, in a very complicated, challenging, and daunting world.

\section{The Other Side of Silence: Where Have All the Animals Gone?}

One means of sanity is to retain a hold on the natural world, to remain, insofar as we can, good animals. (Wallace Stegner 1960) 
The image of the world around us that science provides is highly deficient. It supplies a lot of factual information, and puts all our experience in magnificently coherent order, but it keeps terribly silent about everything close to our hearts, everything that really counts. (Max Schrödinger, as quoted by Revel and Ricard 1998, 214)

The words of Wallace Stegner and Max Schrödinger nicely capture much of what Rachel Carson stood for. We need to be "good" animals and respect other animal beings and a very fragile Earth; we need to step lightly with grace, care, compassion, humility, beneficence, and love, because we can be - and indeed we are - so omnipresent and destructive.

Rachel Carson's warnings about silent springs - silent seasons - must be taken seriously, perhaps even more seriously than when they were penned more than four decades ago. Surely, on the other side of silence, await magic, awe, and Nature's cacophony of sounds - along with a panoply of innumerable other deep, radiant, and vibrant sensory experiences that help us to feel at one with all of Nature. We must be careful never to allow Nature to be silenced.

Each and every individual is part of a communion of subjects (Berry 1999), a vital member of innumerable webs of Nature. Along these lines, recall Carson's words about how interdependent and interconnected we all are: "Here again we are reminded that in nature nothing exists alone" (1962, 51). And:

The inshore waters - the bays, the sounds, the river estuaries, the tidal marshes - form an ecological unit of utmost importance. They are linked so intimately and indispensably with the lives of many fishes, mollusks, and crustaceans that were they no longer habitable these seafoods would disappear from our tables. (Carson 1962, 149)

Carson also stressed that," The predator and the preyed upon exist not alone, but as part of a vast web of life, all of which needs to be taken into account" $(1962,257)$.

Suffice it to say, we are "all in this journey together" - each of us is an integral part of the ongoing story of life and of the panoply of nature's magnificent and wondrous webs.

What befalls animals befalls us. Carson's request that we reconsider our fundamental relationship with Nature, that we undergo an internal revolution, is consistent with the message of ecopsychologists who note that we ourselves feel better when we treat Nature with kindness, respect, and compassion. A close relationship with Nature is critical to our own well-being and spiritual growth.

Silent springs, along with silent summers, falls, and winters, brought about by silencing animals, are not good for us or for other animals. But it is the animals to whom we owe our utmost unwavering respect and concern for their wellbeing, independent of our own. We all need to be careful because it could well ensue that individuals in a future generation will one day wake up and ask "Where have all the animals gone?"

\section{Acknowledgments}

We thank Dale Jamieson and Ned Hettinger for comments on various sections of this essay and Phil Cafaro for reading it all. We also thank Linda Lear for her comments on an ancestral draft of this paper, for personally answering questions that we e-mailed to her, and for clearing up some of our confusion on the phone. None of these people necessarily agrees with our conclusions. 


\section{References}

Bekoff, M. 2000a. Redecorating nature: Reflections on science, holism, humility, community, reconciliation, spirit, compassion, and love. Human Ecology Review 7, 59-67.

Bekoff, M. 2000b. Strolling With Our Kin: Speaking for and Respecting Voiceless Animals. New York: Lantern Books.

Bekoff, M. 2001. Human-carnivore interactions: Adopting proactive strategies for complex problems. In J.L. Gittleman, S.M. Funk, D.W. Macdonald and R.K. Wayne (eds.), Carnivore Conservation, 179-195. New York: Cambridge University Press.

Bekoff, M. 2002. Minding Animals: Awareness, Emotions, and Heart. New York: Oxford University Press.

Bekoff, M. 2003. Minding animals, minding Earth: Old brains in new bottlenecks. Zygon Journal of Religion and Science 38, 911-941.

Bekoff, M. 2004. Human (anthropogenic) effects on animal behavior. In M. Bekoff (ed.), Encyclopedia of Animal Behavior. Westport, CT: Greenwood Publishing Group.

Bekoff, M. and D. Jamieson. 1996. Ethics and the study of carnivores: Doing science while respecting animals. In J.L. Gittleman (ed.), Carnivore Behavior, Ecology, and Evolution, Volume 2, 15-45. Ithaca, NY: Cornell University Press.

Berger, J., S.L. Monfort, T. Roffe, P.B. Stacey and J.W. Testa. 2003. Through the eyes of prey: How the extinction and conservation of North America's large carnivores alter prey systems and biodiversity. In M. Festa-Bianchet and M. Apollonio (eds.), Animal Behavior and Wildlife Conservation, 133-155. Washington, DC: Island Press.

Berry, T. 1999. The Great Work: Our Way into the Future. New York: Bell Tower.

Brooks, P. 1972. The House of Life: Rachel Carson at Work. Boston, MA: Houghton-Mifflin.

Burger, J. 2004. Pollution and behavior. In M. Bekoff (ed.), Encyclopedia of Animal Behavior. Westport, CT: Greenwood Publishing Group.

Cafaro, P. 2002. Rachel Carson's environmental ethics. Worldviews 6, 58-80.

Carson, R. 1962. Silent Spring. Boston, MA: Houghton Mifflin.

Carson, R. 1998. In L. Lear (ed.), Lost Woods: The Discovered Writing of Rachel Carson. Boston, MA: Beacon Press.

Crichton, M. 2002. Prey. New York: Avon Books.

Clarren, R. 2003. Harvesting poison. High Country News 29 September, 7-12.

Cornwell, J. 2003. Just following orders. New Scientist 27 September, 25.

Crooks, K.R. and M.E. Soulé, 1999, Mesopredator release and avifaunal extinctions in a fragmented system. Nature 400, 563-566.

DellOmo, G. (ed.). 2002. Behavioral Ecotoxicology. New York: John Wiley and Sons.

Eisler, P. 2003. Law on pesticides reinterpreted. USA Today 6 October, 3A.

Elliot, R. 1997. Faking Nature: The Ethics of Environmental Restoration. New York: Routledge.

Estes, J.A. 1998. Concerns about rehabilitation of oiled wildlife. Conservation Biology 12, 1156-1157.

Francione, G.L. 2000. Introduction to Animal Rights: Your Child or the Dog? Philadelphia, PA: Temple University Press.

Gartner, C. 1983. Rachel Carson. New York: Frederick Unger.

Goodall, J. and M. Bekoff. 2002. The Ten Trusts: What We Must Do To Care For The Animals We Love. San Francisco, CA: HarperCollins.

Hargrove, E.C. (ed.). 1992. The Animal Rights/Environmental Ethics Debate: The Environmental Perspective. Albany, NY: SUNY Press.

Huff, J. 1998. Stop pesticides: Bugs are better. The Prism. www.ibiblio.org/prism/apr98/bugs.html. Accessed 5 May 2004.

Izakson, O. 2004. Farming infertility. E: The Environmental Magazine January/February, 40-41.

Jamieson, D. 1998. Animal liberation is an environmental ethic. Environmental Values 7, 41-57. 
Krimsky, S. 2003a. A conflict of interest. New Scientist 30 August, 21.

Krimsky, S. 2003b. Science in the Private Interest. New York: Rowman and Littlefield.

Lear, L. 1997. Rachel Carson: Witness for Nature. New York: Henry Holt and Company.

Lee, J. 2003. Popular pesticide faulted for frogs' sexual abnormalities. New York Times 19 June.

Norwood, V. 1993. Rachel Carson and her colleagues. In V. Norwood (ed.), Made From This Earth, 143-

171. Chapel Hill, NC: The University of North Carolina Press.

Pearce, F. 2003. Pesticide industry won't pay its dues. New Scientist 14 June, 8.

Regan, T. 1983. The Case for Animal Rights. Berkeley, CA: University of California Press.

Revel, J.F. and M. Ricard. 1998. The Monk and the Philosopher: A Father and Son Discuss the Meaning of Life. New York: Schocken Books.

Singer, P. 1990 Animal Liberation, 2nd Edition. New York: New York Review of Books.

Smith, D. 2003. Yellowstone after wolves. BioScience 53, 330-340.

Stegner, W. 1960. Wilderness Letter. www.wilderness.org/Ourlssues/Wilderness/wildernessletter.cfm

Tear, T., M. Scott, P. Hayward and B. Griffith. 1993. Status and prospects for success of the endangered species act: A look at recovery plans. Science 262, 976-977.

Waddell, C. 2000. The reception of Silent Spring: An introduction. In C. Waddell (ed.), And No Birds Sing: Rhetorical Analyses of Rachel Carson's Silent Spring, 1-16. Carbondale, IL: Southern Illinois University Press.

Weil, Z. 2003. Above All, Be Kind. Gabriola Island, B.C., Canada: New Society Publishing.

Wood, H.A. 1997. Risks and safety of insecticides: Chemicals vs. natural and recombinant viral pesticides. Bioline International. www.bioline.org.br/request?by97007. Accessed 5 May 2004.

Wunderlich, G. 2004. Evolution of the stewardship idea in American country life. Journal of Agricultural and Environmental Ethics 17, 77-93.

Zimmerman M E., J.B. Callicott, G. Sessions, K.J. Warren and J. Clark (ed.). 1993. Environmental Philosophy: From Animal Rights to Radical Ecology. New York: Prentice-Hall. 